\title{
Assessment of the Efficiency of Resource Potential Employment by the Communities of lviv Region of Ukraine
}

\author{
Ihor Yatsiv ${ }^{1}$, Roman Khirivskyi ${ }^{1}$, Tymofii Pasichnyk ${ }^{2}$, Liudmyla Petryshyn ${ }^{1}$ and \\ Lesia Kucher ${ }^{3}$
}

\begin{abstract}
The article supplies assessment of the efficiency of resource potential employment by some communities in Lviv region. The work studies the main sources of the resources of amalgamated territorial communities and makes grouping of them according to the criteria of their essence and importance in the strategy of development of the community's resource potential. The research analyzes financial capability of the communities, considers the recent results, obtained by Ukrainian scientists concerning the resource potential of amalgamated territorial communities. The authors of the work applied the methods of standard coefficients to transfer the indices of quantity into quality analogues. The indices were used to make rating of amalgamated territorial communities, to depict different factorial and resultant aspects of the resource potential of amalgamated territorial communities and assess them. Applyng the method of standard coefficients and matrix of the Boston Consulting Group, the work determines position of each community referring to density of population and resource of the capacity for work of amalgamated territorial communities. It also calculates rating indices for comparison of public formations in social sphere, and estimates expenditures for administrative personnel of each community. The proposed methods enable keeping track with not only dynamics of the rating assessment of communities, but also priority of the factorial indices concerning improvement and development of the communities. Those methods can be used not just referring to rural, but also to urban formations, based on a uniform measuring for all peculiarities. It helps to move from subjectivism and inconvenient use of expert assessments and weighting coefficients while completing the uniform integrated indices.
\end{abstract}

Keywords: territorial community; social development; resource support; administrative and territorial reform; method of standard coefficients; matrix of the Boston Consulting Group.

\section{Introduction}

Development of market relations in Ukraine occurs along with strengthening of economic independence of business entities, distinguishing of the subjects of state power exercising and local self-government. It intensifies strategic focuses of the compensatory strategy of resource potential development in public formations.

Hence, there is an objective necessity of efficient employment of resource potential of public formations, support of effective distribution of resources, maximum satisfaction of social needs and improvement of living standards of population in public formations, search for the ways to improve the mechanisms of managerial and weatherplanning activity at the level of business entities of communities. Thus, the reform of

${ }^{1}$ Lviv National Agrarian University, Lviv, Ukraine.

${ }^{2}$ Ivan Franko National University of Lviv, Lviv, Ukraine.

${ }^{3}$ Kharkiv National Agrarian University named after V. V. Dokuchayev, Kharkiv, Ukraine. 
local self-government, which is currently in the progress in Ukraine, requires deep scientific argumentation and comparative assessment of strategies, models and projects.

Ukrainian scientists have obtained sufficient results in formation of scientific approaches to solution of the problems of social-economic development of regions in the country.

In particular, resource potential of amalgamated territorial communities (ATC) is studied in the works by O. Yu. Kucherenko, I. V. Zapatrina [13], V. M. Babaiev, M. M. Novikova [2], D. M. Savchuk [19], T. M. Bezverkhniuk [6] and others. The issues of communities development are considered in the works by I. V. Honcharenko [9], N. M. Makhnachova [14], Yu. M. Petrushenko [16] and others.

The significance of the entrepreneurial potential of rural territories as an object of scientific research is due to the prospects of the theoretical, methodological and applied provision of this potential in particular, considering its integration (aggregate) features, the resource component, the environment for its reproduction, the effective use of institutional, managerial, and endogenous potentials [12].

The article assessed the food market potential capacity in rural settlements per 1000 habitants, according to which a production business-model of rural areas development in Ukraine on the basis of small business units for the production of agrifood products has been proposed [7].

The main aspects of the US rural development policy that can be implemented under Ukrainian conditions are defined in the article by O. Prokopchuk and I. Gorbachova [18]. The scientific novelty of the investigation by O. Kononenko is the determination of land resources as the priority factor of a self-sufficient rural areas development in modern times and conditions. In this paper the primary institutional and legal contradictions of the land relations regulation mechanism in the context of sustainable development of the rural territories are determined [11]. This issue is of particular relevance in the context of the agricultural land market [8] and widespread degradation processes in soils in Ukraine [5].

The focus of the paper by M. Babych is to determine opportunities for developing rural territories in Ukraine on the basis of the development of short supply chains in terms of ensuring social, economic and environmental sustainability. It is established that such an approach provides sustainable development of rural territory [3]. In the paper by M. Plotnikova describes alternative settlement as a system of socioeconomic and environmental development of rural areas and balanced self-development of territorial communities in Ukraine [17].

Evaluation of sustainability of agriculture during European Union Common Agricultural Policy implementation is among the most topical issues [4].

However, in economic literature, methods of correlation, factorial analysis, expert estimates and other methods are used for assessment of public formations development with determination of an integral index. Application of a uniform integral index has some essential drawbacks. To assess competitive capacity of the compensatory strategy of resource potential use it is reasonable to apply the method of standard coefficients [10, p. 132]. That method is used to link the data according to different quantitative indices to a common scale and excludes the impact of different measuring units on the ultimate result. 


\section{Materials and Methods}

The aim of the article is to assess competitive capacity of the compensatory strategy of resource potential use by some amalgamated territorial communities in Lviv region using the method of standard coefficients.

To transform the figures of indices into quality analogues, the following methods were used [15]. All variables of $x$ possess a value on the segment $[0,1](0-$ is a minimum (the worst) value, 1 - is a maximum (the best) value of the variable).

$$
\dot{x}_{i}=\frac{\left(x_{i}-x_{\min }\right)}{\left(x_{\max }-x_{\min }\right)}
$$

Analyzing the obtained coefficients, one can complete the rating of amalgamated territorial communities, where the highest score characterizes a public formation of the highest competitive capacity in terms of the chosen indices of the compensatory policy of resource potential use in the community.

In the investigation, 19 indicators were used (land area of the community; area in percent to the total area of the district and region; population in total and the population of younger than working age; working-age population; population of older than working age; children of preschool and school age; number of operating enterprises, farms; number of small enterprises, individual entrepreneurs, etc.). To complete the rating, the researchers used the data from the Table 1 and Table 2.

Table 1: Main figures of indices of amalgamated territorial communities

\begin{tabular}{|c|c|c|c|c|c|c|c|c|}
\hline \multirow[b]{2}{*}{ Indices } & \multicolumn{8}{|c|}{ Communities } \\
\hline & 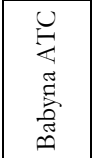 & 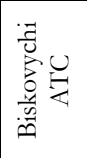 & 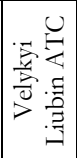 & 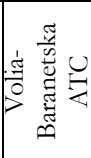 & 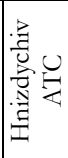 & 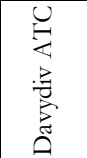 & 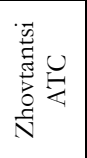 & 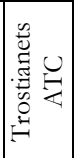 \\
\hline Area & 77.2 & 55 & 132.5 & 69.4 & 57.6 & 78.5 & 130.93 & 190.4 \\
\hline Area in $\%$ to the total area of the district & 8.27 & 5.89 & 18.25 & 7.43 & 5.7 & 8.3 & 15.08 & 28.21 \\
\hline Area in $\%$ to the total area of the region & 0.35 & 0.25 & 0.61 & 0.32 & 0.26 & 0.36 & 0.6 & 0.87 \\
\hline Population & 4134 & 5567 & 9626 & 5330 & 6632 & 12283 & 8950 & 8087 \\
\hline Population of younger than the working age & 705 & 1165 & 1916 & 913 & 1388 & 2847 & 1801 & 1628 \\
\hline Working-age population & 2483 & 3251 & 5891 & 3204 & 3873 & 7544 & 5913 & 4955 \\
\hline Population of older than the working age & 946 & 1151 & 1819 & 1213 & 1371 & 2239 & 1211 & 1504 \\
\hline Preschool-aged children & 247 & 442 & 638 & 413 & 444 & 1072 & 715 & 641 \\
\hline School-aged children & 456 & 659 & 931 & 450 & 913 & 1212 & 1086 & 726 \\
\hline Number of operating enterprises, farms & 11 & 15 & 22 & 10 & 17 & 228 & 41 & 20 \\
\hline Number of small enterprises, individual entrepreneurs & 21 & 27 & 73 & 23 & 42 & 502 & 137 & 33 \\
\hline The average salary in the community & 4200 & 4325 & 4657 & 3200 & 5550 & 7104 & 7600 & 4295 \\
\hline Budget of the community, revenues, thsd. UAH & 12009.7 & 16969.1 & 5536 & 18202.5 & 32735 & 85199.3 & 52841.9 & 60514 \\
\hline Budget of the community, expenditures, thsd. UAH & 12129.8 & 15950.9 & 5733 & 18164.5 & 31629 & 84495.3 & 53898.7 & 60514 \\
\hline Healthcare facilities & 8 & 6 & 10 & 7 & 4 & 6 & 9 & 12 \\
\hline Cultural institutions & 8 & 5 & 15 & 6 & 12 & 13 & 9 & 28 \\
\hline Internal fund per one resident & 1881.1 & 2081.6 & 1839.8 & 992.3 & 499.8 & 887.9 & 356.1 & 838 \\
\hline $\begin{array}{l}\text { Level of budget subvention (a share of basic/reverse } \\
\text { subsidies in revenues), \%. }\end{array}$ & 11.5 & -5.1 & 16.5 & 26.7 & 44.4 & 30.4 & 55.8 & 30.3 \\
\hline Share of expenditures for administrative personnel & 29.5 & 10.7 & 29.5 & 37.8 & 40.7 & 32.1 & 56.9 & 42.7 \\
\hline
\end{tabular}

Source: developed according to the data about communities and electronic resource [1]. 
Table 2: Quality analogues to the figures of indices of amalgamated territorial communities

\begin{tabular}{|c|c|c|c|c|c|c|c|c|}
\hline \multirow[b]{2}{*}{ Indices } & \multicolumn{8}{|c|}{ Communities } \\
\hline & 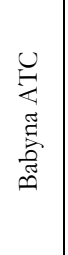 & 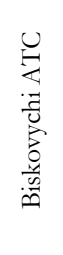 & 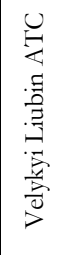 & 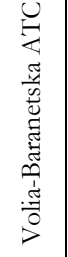 & 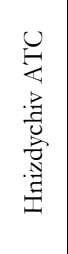 & 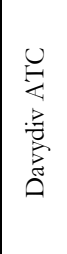 & 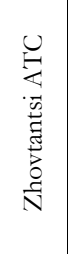 & 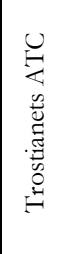 \\
\hline Area & 0.16 & 0.00 & 0.57 & 0.11 & 0.02 & 0.17 & 0.56 & 1.00 \\
\hline Area in $\%$ to the total area of the district & 0.11 & 0.01 & 0.56 & 0.08 & 0.00 & 0.12 & 0.42 & 1.00 \\
\hline Area in $\%$ to the total area of the region & 0.16 & 0.00 & 0.57 & 0.11 & 0.02 & 0.17 & 0.56 & 1.00 \\
\hline Population & 0.00 & 0.18 & 0.67 & 0.15 & 0.31 & 1.00 & 0.59 & 0.49 \\
\hline Population of younger than the working age & 0.00 & 0.21 & 0.57 & 0.10 & 0.32 & 1.00 & 0.51 & 0.43 \\
\hline Working-age population & 0.00 & 0.15 & 0.67 & 0.14 & 0.27 & 1.00 & 0.68 & 0.49 \\
\hline Population of older than the working age & 0.00 & 0.16 & 0.68 & 0.21 & 0.33 & 1.00 & 0.20 & 0.43 \\
\hline Preschool-aged children & 0.00 & 0.24 & 0.47 & 0.20 & 0.24 & 1.00 & 0.57 & 0.48 \\
\hline School-aged children & 0.01 & 0.27 & 0.63 & 0.00 & 0.61 & 1.00 & 0.83 & 0.36 \\
\hline Number of operating enterprises, farms & 0.00 & 0.02 & 0.06 & 0.00 & 0.03 & 1.00 & 0.14 & 0.05 \\
\hline Number of small enterprises, individual entrepreneurs & 0.00 & 0.01 & 0.11 & 0.00 & 0.04 & 1.00 & 0.24 & 0.02 \\
\hline The average salary in the community & 0.23 & 0.26 & 0.33 & 0.00 & 0.53 & 0.89 & 1.00 & 0.25 \\
\hline Budget of the community, revenues, thsd. UAH & 0.08 & 0.14 & 0.00 & 0.16 & 0.34 & 1.00 & 0.59 & 0.69 \\
\hline Budget of the community, expenditures, thsd. UAH & 0.08 & 0.13 & 0.00 & 0.16 & 0.33 & 1.00 & 0.61 & 0.70 \\
\hline Healthcare facilities & 0.50 & 0.25 & 0.75 & 0.38 & 0.00 & 0.25 & 0.63 & 1.00 \\
\hline Cultural institutions & 0.13 & 0.00 & 0.43 & 0.04 & 0.30 & 0.35 & 0.17 & 1.00 \\
\hline Internal fund per one resident & 0.88 & 1.00 & 0.86 & 0.37 & 0.08 & 0.31 & 0.00 & 0.28 \\
\hline $\begin{array}{l}\text { Level of budget subvention (a share of basic/reverse subsidies } \\
\text { in revenues), } \%\end{array}$ & 0.27 & 0.00 & 0.35 & 0.52 & 0.81 & 0.58 & 1.00 & 0.58 \\
\hline Share of expenditures for administrative personnel & 0.41 & 0.00 & 0.41 & 0.59 & 0.65 & 0.46 & 1.00 & 0.69 \\
\hline
\end{tabular}

Source: calculated by the authors basing the formula (1).

The figures, taken from the Tables, depict different factorial and resultant aspects of the resource potential of the communities. The Figure 1 presents a system of indicative indices of the compensatory strategy of the resource potential development by the communities.

Using the method of standard coefficients and the BCG-matrix (Boston Consulting Group matrix), one can precisely determine the position of each community, considering a pair comparison of resultant and factorial indices. 


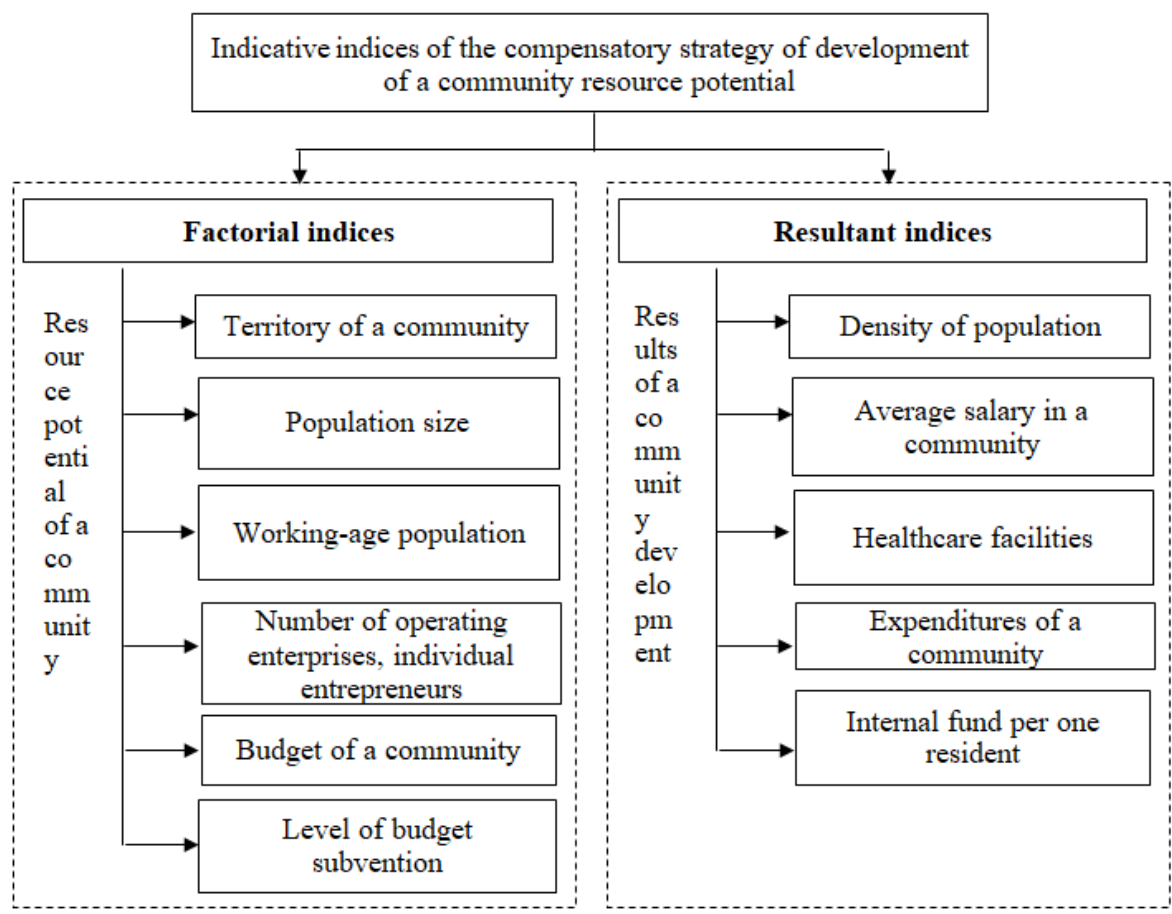

Figure 1: System of indicative indices of the compensatory strategy of development of a community resource potential Source: calculated by the authors.

\section{Results}

Differentiation of public formations according to the population and size of those formations influences density of population in those communities. Figure 2 demonstrates that maximum density of population per a unit of territory is marked in Trostianets ATC, high density of population per a unit of territory is also observed in Babyna ATC, Velykyi Liubin ATC, Volia-Baranetska ATC and Zhovtantsi ATC. The least density of population is marked in Davydiv ATC.

From the point of labor potential employment at public formations, it is reasonable to compare the indices of "population size - working-age population", as it is presented by the Figure 3 .

Figure 3 shows that the correlation of working-age population to the total number is almost similar in all communities and stays within 0.58-0.66. However, engagement of labor resources of Babyna ATC and Volia-Baranetska ATC is a little lower than in the other amalgamated territorial communities. The similar picture can be seen under comparison of the indices of "population size - younger than working-age population". 


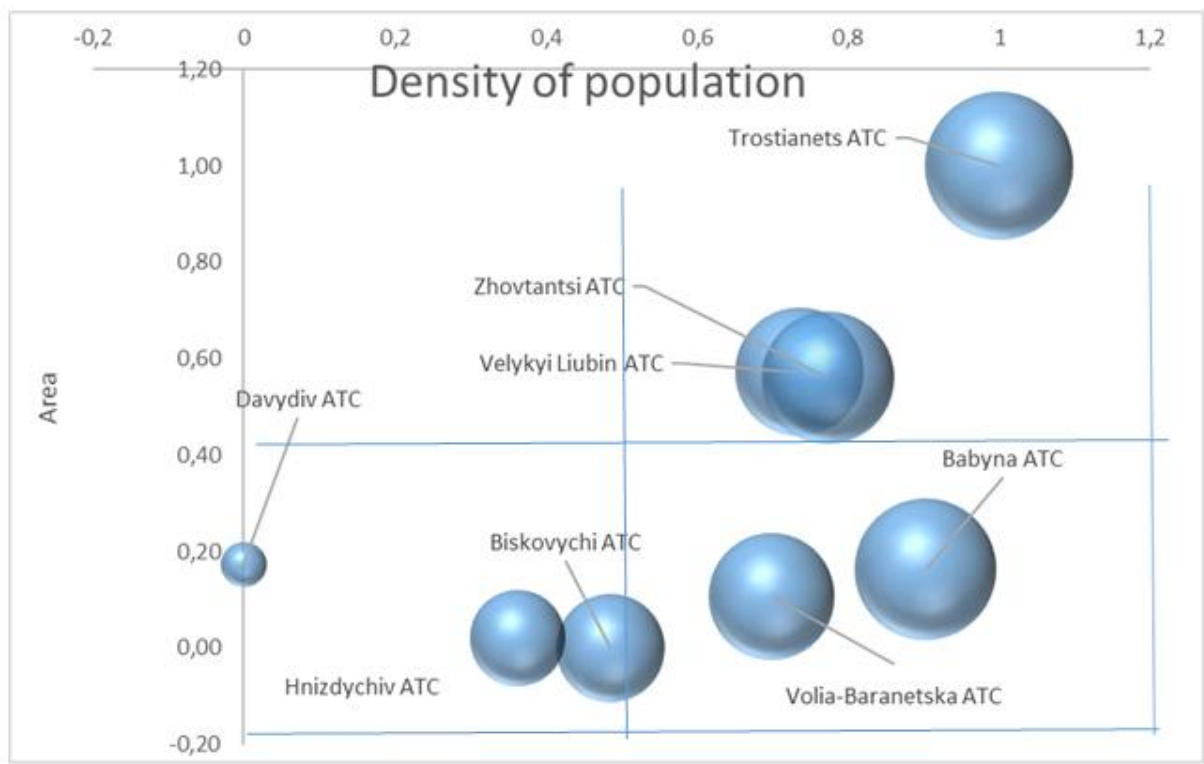

Figure 2: Comparison of the indices of "density - area"

Source: calculated by the authors.

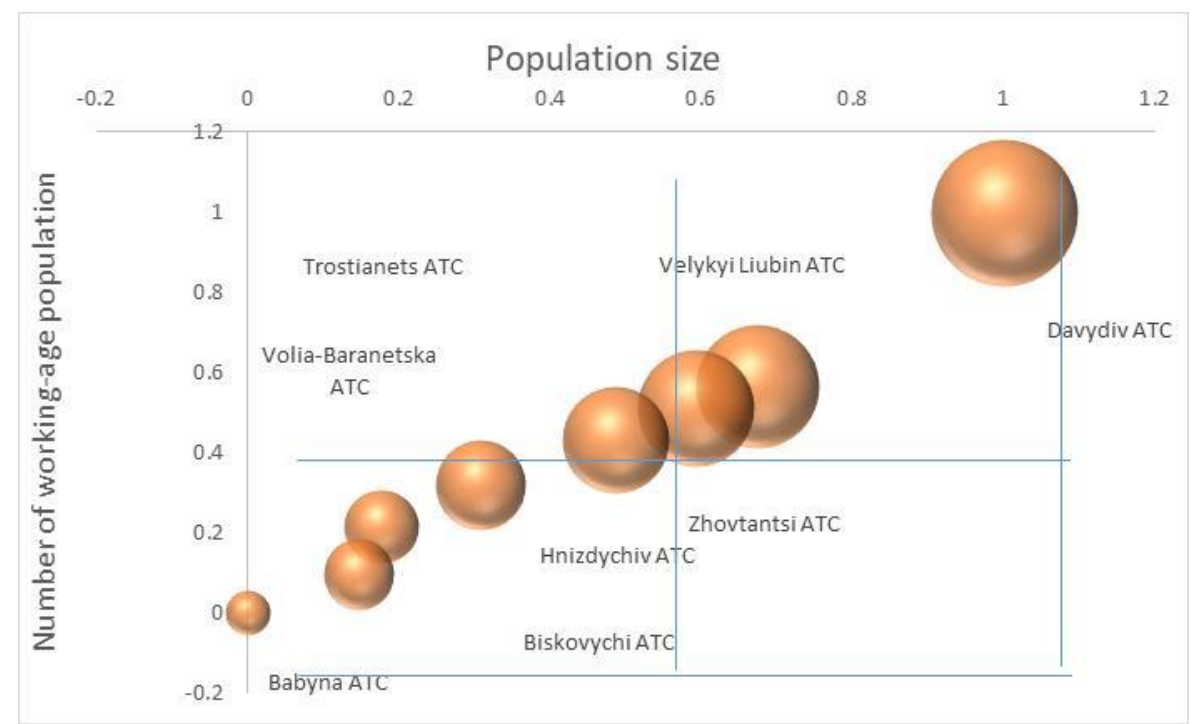

Figure 3: Comparison of the indices of "population size - working-age population"

Source: calculated by the authors.

Comparing the pairs of the following indices of "number of enterprises - annual average number of employed people", one can make the conclusion that the leading positions are taken by Davydiv ATC. Favorable conditions concerning opportunities of labor potential employment are marked in Zhovtantsi ATC, Valykyi Liubin ATC and Trostianets ATC, as they are in the fourth quadrant of the Boston matrix - Figure 4. 


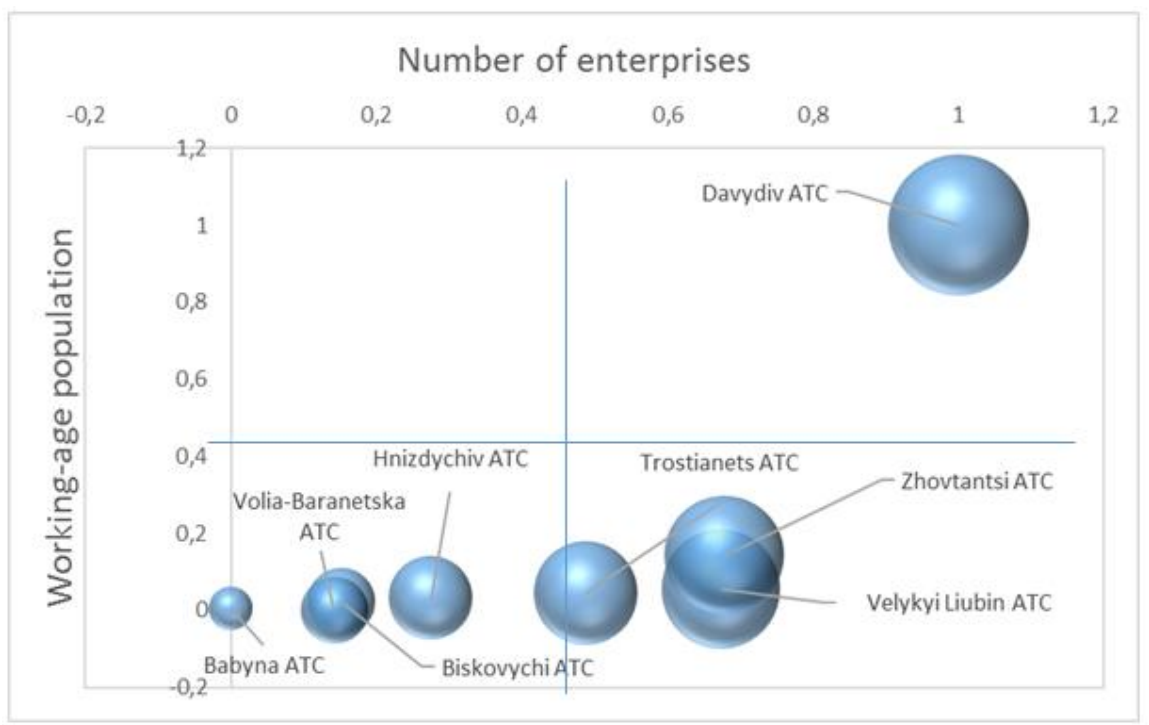

Figure 4: Comparison of the indices of "number of enterprises - working-age population" Source: calculated by the authors.

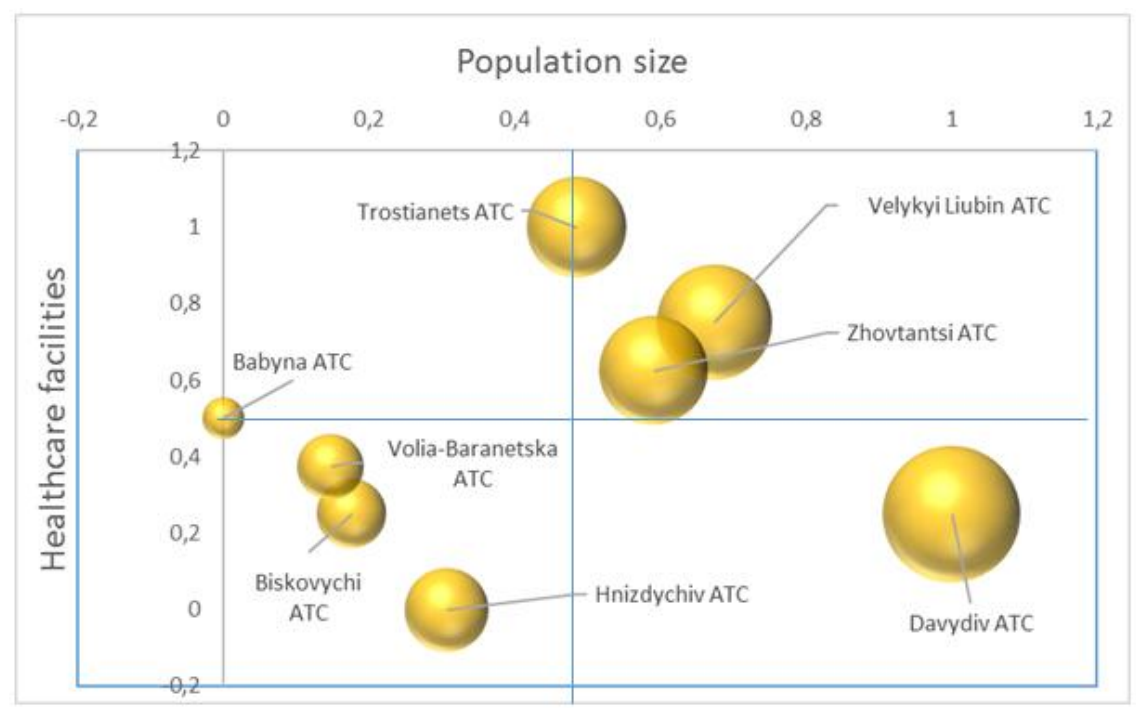

Figure 5: Comparison of the indices of "population size - number of healthcare facilities" Source: calculated by the authors.

Indicative indices, which are grouped into the pairs of "population size cultural institutions", demonstrate rating indices of the comparison of public formations in the social policy. These indices are depicted at the Figure 5 and Figure 6. 


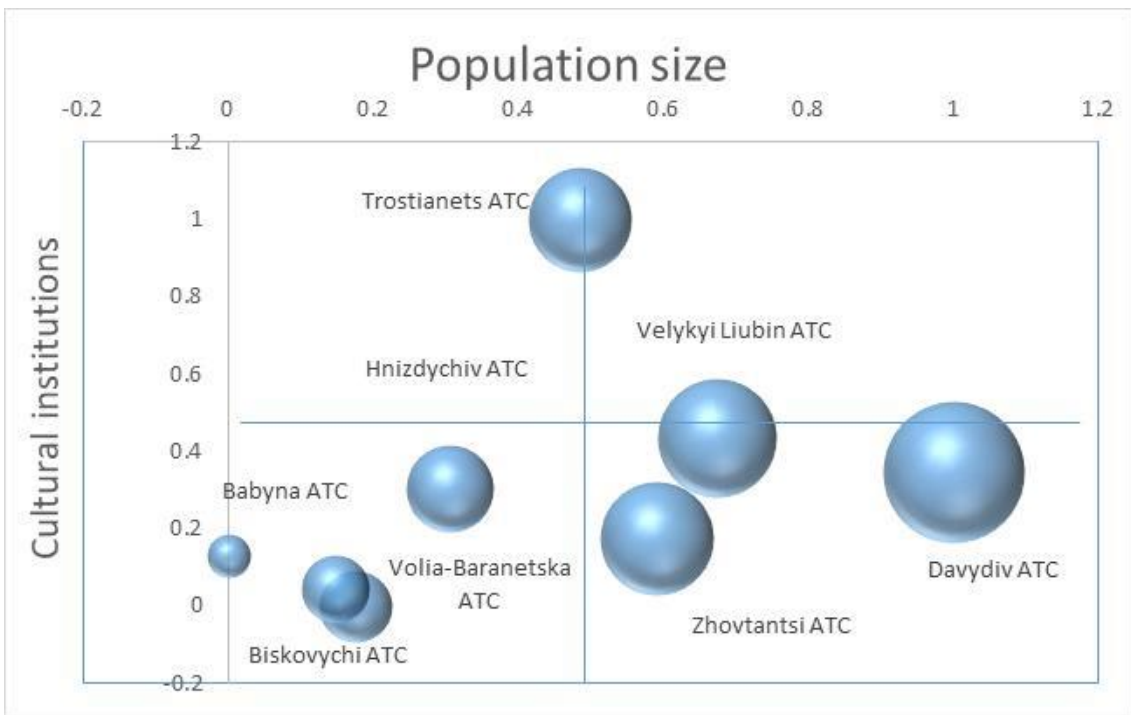

Figure 6: Comparison of the indices of "population size - number of cultural institutions" Source: calculated by the authors.

Figure 5 demonstrates that the least share of population per a unit of healthcare facilities is in Babyna ATC, and the largest one - in Davydiv ATC. Particular, in absolute values, in Babyna ATC there 517 people per one healthcare establishment, and 2047 people - in Davydiv ATC.

Comparing the indices of "population size - number of cultural institutions", the best position is taken by Trostianets ATC, and the worst - by Biskovychi ATC. In absolute values, in Trostianets ATC, there are 229 people per one cultural institution, and in Biskovychi ATC - 1113 people.

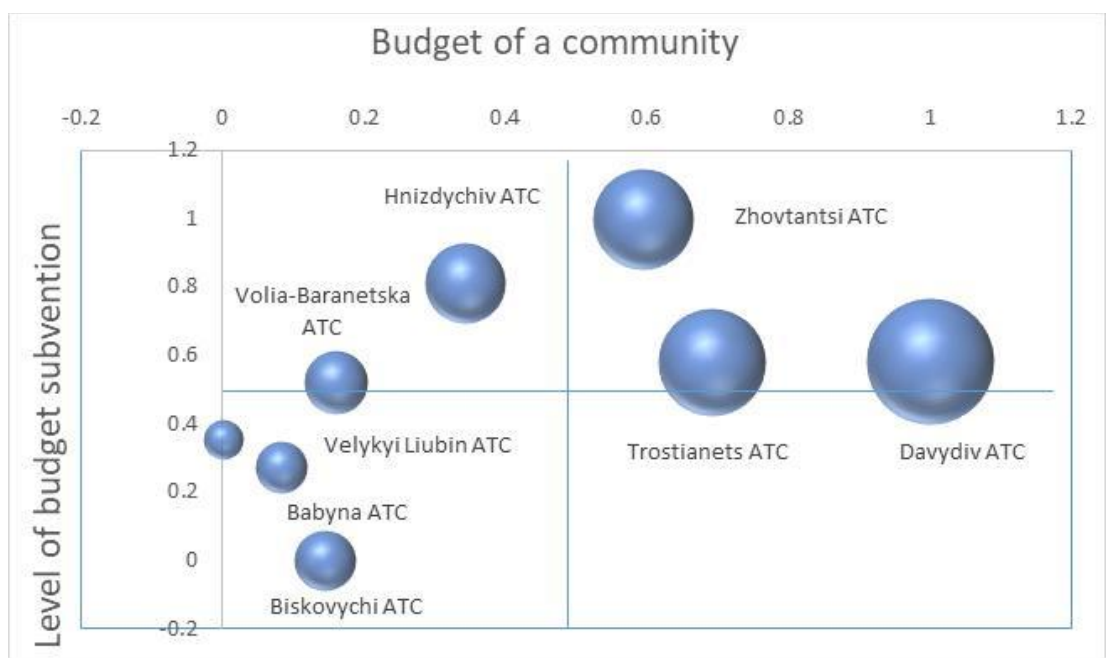

Figure 7: Comparison of the indices of "budget of a community - level of budget subvention"

Source: calculated by the authors. 
Comparing the pairs of indices of "budget of a community - level of budget subvention", i.e. Figure 7, one can observe that leading position is taken by Zhovtantsi ATC. It is worth mentioning that in all communities, the level of reverse subvention is sufficiently higher than the share of basic subsidies.

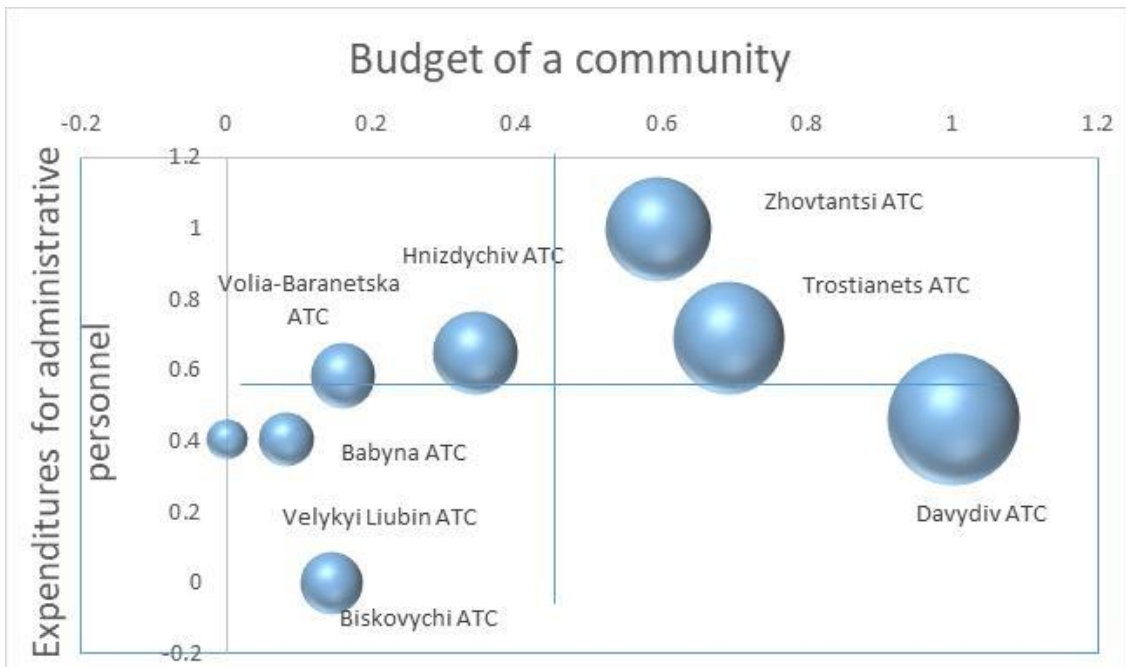

Figure 8: Comparison of the indices of "budget of a community - share of expenditures for administrative personnel"

Source: calculated by the authors.

Comparing the pairs of indices of "budget of a community - share of expenditures for administrative personnel", i.e. Figure 8, one should note that the maximum expenditures for administrative personnel are particular for Zhovtantsi ATC, and the indices of all communities are outside the fourth quadrant of the Boston matrix. It confirms inefficient use of fund for administrative personnel maintenance. To increase the efficiency of administration of the resource potential, we propose to widely apply the project approach. The development and implementation of innovation and investment projects will contribute to the sustainable development of ATC.

\section{Conclusions}

Resource potential of amalgamated territorial communities is the basis for raise of the level of financial capabilities of local budgets and development of the corresponding territories. However, in the process of decentralization and establishment of amalgamated territorial communities, most of them face the challenges of efficient use of its resource potential. The fact forces the necessity of an adequate understanding of the nature of resource potential of a community and high efficiency of its employment.

The article proposes methods to keep track with the dynamics of not only rating assessment of communities, but also to determine which factorial indices can be improved by a particular focus of the community leaders. It provides the opportunity to 
regulate the quality of managerial activity of public formations on the ground of rational system of monitoring of their activity results.

The work develops indicative methods for assessment of strategic focuses of the compensatory strategy of resource potential use by public formations. There is a flexible complex of indicators (resultant and factorial indices), which help to assess efficiency of different directions of a community activity, using the methods of ranging.

Thus, the method of standard coefficients enables rating assessment of strategic focuses of the compensatory policy of public formations with consideration of the aim and different aspects of comparative analysis, securing the following comparison of the chosen resultant and factorial indices on the base of the Boston matrix. The proposed methods can be used both concerning rural and urban communities with application of a uniform measuring aspect for all expert estimates and weight coefficients while completing the uniform integral indices.

\section{References}

Assessment of financial capability of 366 ATC for the first half of 2017. Available at: https://www.kmu.gov.ua/storage/app/media/reforms/53-rezultati-finansovogo-monitoringu366-otg-za-1 pivrichchya-2017-roku-stvorenikh-u-2015-ta-2016-rokakh.pdf.

Babaiev, V. M. and Novikova, M. M. (2015). Modern approaches to maintenance and growth of resource potential of territorial communities. Kharkiv. 198 p.

Babych, M. (2018). Social-economic and environmental sustainability of short supply chains: opportunities for development rural territories. Agricultural and Resource Economics: International Scientific E-Journal, 4(1): 42-59. Available at: http://are-journal.com.

Bachev, H. (2017). Socio-economic and environmental sustainability of Bulgarian farms. Agricultural and Resource Economics: International Scientific E-Journal, 3(2): 5-21. Available at: http://are-journal.com.

Baliuk, S. A., Solovey, V. B., Zakharova, M. A., Kucher, A. V. and Truskavetskyi, S. R. (2015). Analysis of Information Support for the Condition of Soil Resources in Ukraine. Agricultural Science and Practice, 2(2): 77-84. https://doi.org/10.15407/agrisp2.02.077.

Bezverkhniuk, T. M. (2008). Space-time characteristics of the resources of regional management. Actual problems of state management, 2(34): 10-17.

Chemerys, V., Dushka, V., Maksym, V. and Solomonko, D. (2019). Business-model of rural areas development in Ukraine. Agricultural and Resource Economics: International Scientific E-Journal, 5(1): 154-176. Available at: http://are-journal.com.

Heldak M., Stacherzak A. and Kucher A. (2017). Analysis of the changes in transaction prices of agricultural land in Poland. Hradec Economic Days 2017: double-blind peer reviewed proceedings of the international scientific conference, 31 January - 1 February 2017. Hradec Králové: University of Hradec Králové, 2017. Pp. 287-295.

Honcharenko, I. V. (2009). Social-economic development of rural area of the region: problems of theory and practice. Lviv: Institute of Regional Investigations. 370 p.

Ihnatov, V. H. and Butov, V. I. (2005). Local self-government: Russian practice and foreign experience: manual. Moscow: Rostov-n/D. 247 p.

Kononenko, O. (2019). Transformation of land relations regulation mechanism throughout the rural sustainable development context. Agricultural and Resource Economics: International Scientific E-Journal, 5(1): 19-36. Available at: http://are-journal.com.

Kravchuk, I. and Rakovich, A. (2018). Entrepreneurial potential of rural territories as an object of scientific research. Agricultural and Resource Economics: International Scientific E-Journal, 4(2): 69-84. Available at: http://are-journal.com.

Kucherenko, O. Yu. and Zapatrina, I. V. (2006). State administration: plans and projects of economic development. Kyiv, VIP. 624 p. 
Makhnachova, N. M. (2016). Social mobilization and resource potential of a community. Efficient economy, 10. Available at: www.economy.nayka.com.ua/?op $=1 \& z=5175$.

Pasichnyk, T. V., Kucher, A. V. and Khirivskyi, R. P. (2016). Efficiency of agrarian enterprises of different organizational-legal forms and sizes of land use. Actual problems of economy, 1(175): 399-405.

Petrushenko, Yu. M. (2014). Local development with participation of a community: monograph: in 2 vol. Sumy: University book. Vol. 2: Institutional and applied aspects of local development management, book. 368 p.

Plotnikova, M. (2017). Formation of communities ancestral estate as foundation of rural development in the context of authority decentralization. Agricultural and Resource Economics: International Scientific EJournal, 3(3): 103-118. Available at: http://are-journal.com.

Prokopchuk, O. and Gorbachova, I. (2018). System of institutional and investment support of rural areas development in the USA. Agricultural and Resource Economics: International Scientific E-Journal, 4(2): 115-128. Available at: http://are-journal.com.

Savchuk, D. M. (2018). Characteristics of resource potential of a community and assessment of efficiency of its employment. Ukrainian journal of applied economics, 3(1): 83-94. 
